\title{
Economics Recession and Historically Black Colleges and Universities: An Analysis of Factors Impacting Historically Black Colleges and Universities
}

\author{
Matthew Uwakonye ${ }^{1} \&$ Gbolahan S. Osho, \\ ${ }^{1}$ Grambling State University, USA \\ ${ }^{2}$ Prairie View A\&M University, USA \\ *Corresponding author: Prairie View A\&M University \\ E-mail: gbosho@yahoo.com
}

Received: August 16, 2012 Accepted: September 23, 2012 Published: December 25, 2012

doi:10.5296/ije.v4i4.2254 URL: http://dx.doi.org/10.5296/ije.v4i4.2254

\begin{abstract}
The primary purpose of this research study is to know how recession affected Historically Black Colleges and Universities. Analysis was based on data obtained from the schools' fact books. The HBCU's chosen were Grambling State University, Southern University Baton Rouge, Alabama A\&M University and Prairie View A\&M University. The Non-Historically Black Colleges and Universities were used for comparison. GSU, Southern University Baton Rouge, Alabama A\&M University and Prairie View A\&M University all lost their percentage of a state appropriations for 2005and 2007. Louisiana Tech was the only school that went from negative to positive in percentage of state appropriation. From the state appropriations chart downturn could negatively impact factors of success for each university. In addition to the state appropriations; tuition, alumni resources, and other school fees all impacted the Universities' revenue for each year. Each of the schools maintained a consistent percentage change rate. Enrollments declined and at the same time endowments dropped and fundraising sources dried up.
\end{abstract}

Keywords: recession; HBCU; inflation; tuition; enrollments; revenue; appropriations 


\section{Introduction}

The United States of America is beyond a doubt a powerful country held by its promise of prosperity, and a chance at wealth through our economy. However, lately it has been impacted by a horrible plague. This plague is called downturn. Downturn is defined as a period or trend in which business or economic activit6y is reduced or is less successful (World English Dictionary). The current recession that our country is experiencing is said to impact future state appropriations for higher education. Namely, in addition to other factors such as weaker alumni resources, downturn is impacting Historically Black Colleges and Universities at an alarming rate. The HBCU's that we have chosen to analyze are Grambling State University, Southern University Baton Rouge, Alabama A\&M University, and Prairie View A\&M University. The Non-Historically Black Colleges and Universities control that we have chosen to compare them is Louisiana Tech University.

\section{Method}

This model relates inflation less trend inflation to past values provides a useful starting point for assessing changes in the behavior of inflation.

$$
\mathrm{U}_{\mathrm{t}}-\mathrm{U}_{\mathrm{t}}^{\mathrm{b}}=\alpha_{1}\left(\mathrm{U}_{\mathrm{t}-1}-\mathrm{U}_{\mathrm{t}-1}^{\mathrm{b}}\right)+\alpha_{2}\left(\mathrm{U}_{\mathrm{t}-2}-\mathrm{U}_{\mathrm{t}-2}^{\mathrm{b}}\right)+\mathrm{b}_{\mathrm{t}}
$$

Where $U_{t}$ is denoting core PCE inflation

$\mathrm{U}_{2}^{\mathrm{b}}$ is denoting trend inflation measured as the long-term expectation.

$\alpha_{1}, \alpha_{2}$ are the model coefficients which can be used to determine current inflation from the past values of inflation and inflation expectations.

$\mathrm{b}_{\mathrm{t}}$ is the regression error which captures unexpected changes in detrended inflation and represents the shocks to inflation.

If we the left term into the right we can get:

$$
U_{t}=\alpha_{1} U_{t-1}+\alpha_{2} U_{t-2}-\alpha_{1} U_{t-1}^{b}-\alpha_{2} U_{t-2}^{b}+b_{t}+U_{t}^{b}
$$

If we suppose the moment that inflation expectations move slowly, such that inflation expectations in the past two periods are roughly the same as in the current period. Then the formula can be changed into:

$$
U_{t}=\alpha_{1} U_{t-1}+\alpha_{2} U_{t-2}+\left(1-\alpha_{1}-\alpha_{2}\right) U_{t}^{b}+b_{t}
$$

Which means suppose the $\mathrm{U}_{\mathrm{t}-1}^{\mathrm{b}}=\mathrm{U}_{\mathrm{t}-2}^{\mathrm{b}}=\mathrm{U}_{\mathrm{t}}^{\mathrm{b}}$ we use $\mathrm{U}_{\mathrm{t}}^{\mathrm{b}}$ to replace the other two terms

From above, a large coefficient on inflation expectations implies expectations exert a 


\section{Ml Macrothink}

International Journal of Education

ISSN 1948-5476

2012, Vol. 4, No. 4

significant influence on inflation. A large coefficient on inflation expectations translates into a small value of $\alpha_{1}+\alpha_{2}$, smaller coefficients $\alpha_{1}$ and $\alpha_{2}$ imply a greater influence on long-term expectations on inflation has become more influenced by inflation expectations. Changed in model coefficients could also explain the reduced volatility of inflation in recent years. Alternatively, reduced volatility could be due to a fall in the size of the shocks to inflation.

The model is a vector auto regression with time-varying coefficients and stochastic volatility. The model takes the form:

$$
\alpha_{\mathrm{t}}=\delta_{1, \mathrm{t}} \alpha_{\mathrm{t}-1}+\delta_{2, \mathrm{t}} \alpha_{\mathrm{t}-2}+\varphi_{\mathrm{t}}^{-1} \gamma_{\mathrm{t}}^{\mathrm{E}} \mu_{\mathrm{t}}, \operatorname{var}\left(\mu_{\mathrm{i}}\right)
$$

The errors $\mu_{\mathrm{z}}$ are independent structural shocks, identified from the common recursive, or Choleski, ordering, the reduced-form residuals $\operatorname{are}_{\mathrm{t}}^{-1} \gamma_{\mathrm{t}}^{\mathrm{E}} \mu_{\mathrm{v}}$.

With all the coefficients of $\delta_{1,5}$ and $\delta_{2 \pi}$ Stacked in a vector $B_{t}$, the model can be written as:

$$
\alpha_{\mathrm{t}}=\beta_{\mathrm{t}} \delta_{\mathrm{t}}+\varphi_{\mathrm{t}}^{-1} \gamma_{\mathrm{t}} \boldsymbol{E}_{\mathrm{t}}
$$

Where $\beta_{\mathrm{t}}$ is a stacked vector containing all of the right-hand-side variables for all equations and the time variation of the model parameters is governed by the following equations:

$$
\begin{aligned}
\delta_{\mathrm{t}} & =\delta_{\mathrm{t}-1}+\rho_{\mathrm{t}} \ldots \ldots \\
\varphi_{\mathrm{t}} & =\varphi_{\mathrm{t}-1}+\sigma_{\mathrm{t}} \ldots \ldots \\
\log Y_{\mathrm{t}} & =\log Y_{\mathrm{t}-1}+\mathrm{m}_{\mathrm{t}}
\end{aligned}
$$

\section{Statistical Analysis}

From the schools fact books, out of all the states, Louisiana Tech was only school that went from negative to positive in their percentage of state appropriations. This occurred in 2007. Grambling State University, Southern University Baton Rouge, Alabama A\&M University and Prairie View A\&M University all lost shares of their percentage of state appropriations from the years 2005-2007 consistently. This means that downturn could worsen an already negatively growing impact of funding on state schools. 


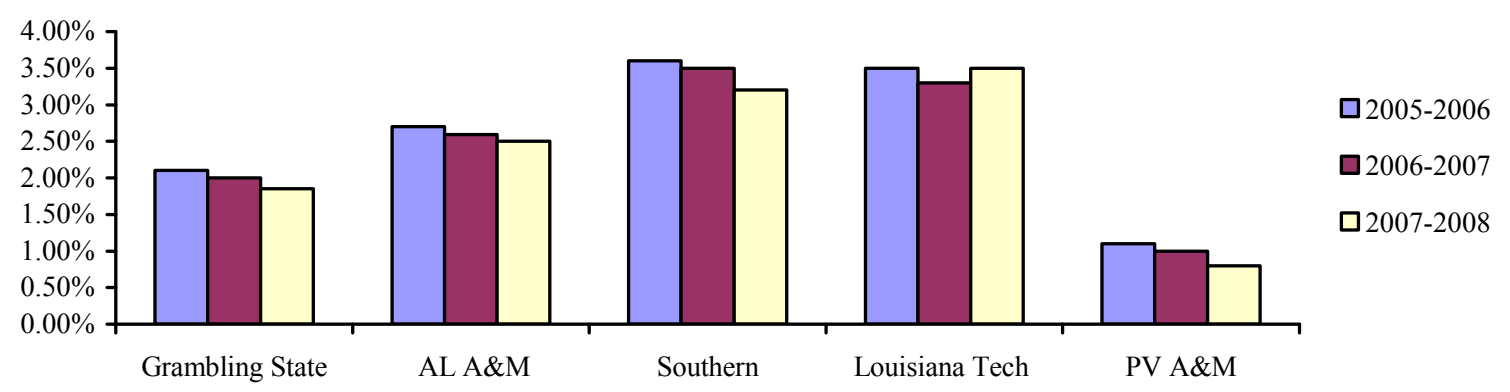

Figure 1: Percent of State Apporiations Over Time

There is yet another negative outcome of downturn facing the UL System. "The Louisiana Board of Regents has identified college and university programs which could be eliminated due to low-completer rates and halted most new academic program approvals" (Board of Regents). One of the universities in the university of Louisiana system is Grambling State University. The Louisiana Board of Regents has identified 6 low-completer programs for Grambling, 11 for Louisiana Tech and 8 for Southern University at Baton Rouge. This means that those major programs currently offered to students will be discontinued. Therefore, should someone have planned to attend those universities with those major choices, they may change their mind and have to attend a different university. Prairie View and Alabama A\&M University may choose to discontinue some of their low-completer programs as well. Some students are so economically unstable that they are considering returning to their home state to pursue a degree with less cost to them. Grambling State University's President stated "With more than $40 \%$ of our students coming from out-of-state and the national impact of our note professional degree programs, we believe that is most important than ever to maintain the integrity of our classrooms" (Ball).

To maintain integrity in the classroom you must keep quality educators, quality programs and quality recruiters. The following chart shows the impact of state appropriations on number of professors employed at each university. WE partnered the information from the Grapevine project at ISU with pulled information from the Online Fact books of Grambling State University, Southern University Baton Rouge, Alabama A\&M University, Prairie View A\&M University and Louisiana Tech University. Alabama A\&M University's information on the number of professors over time could not be found and therefore was omitted from this analysis. 


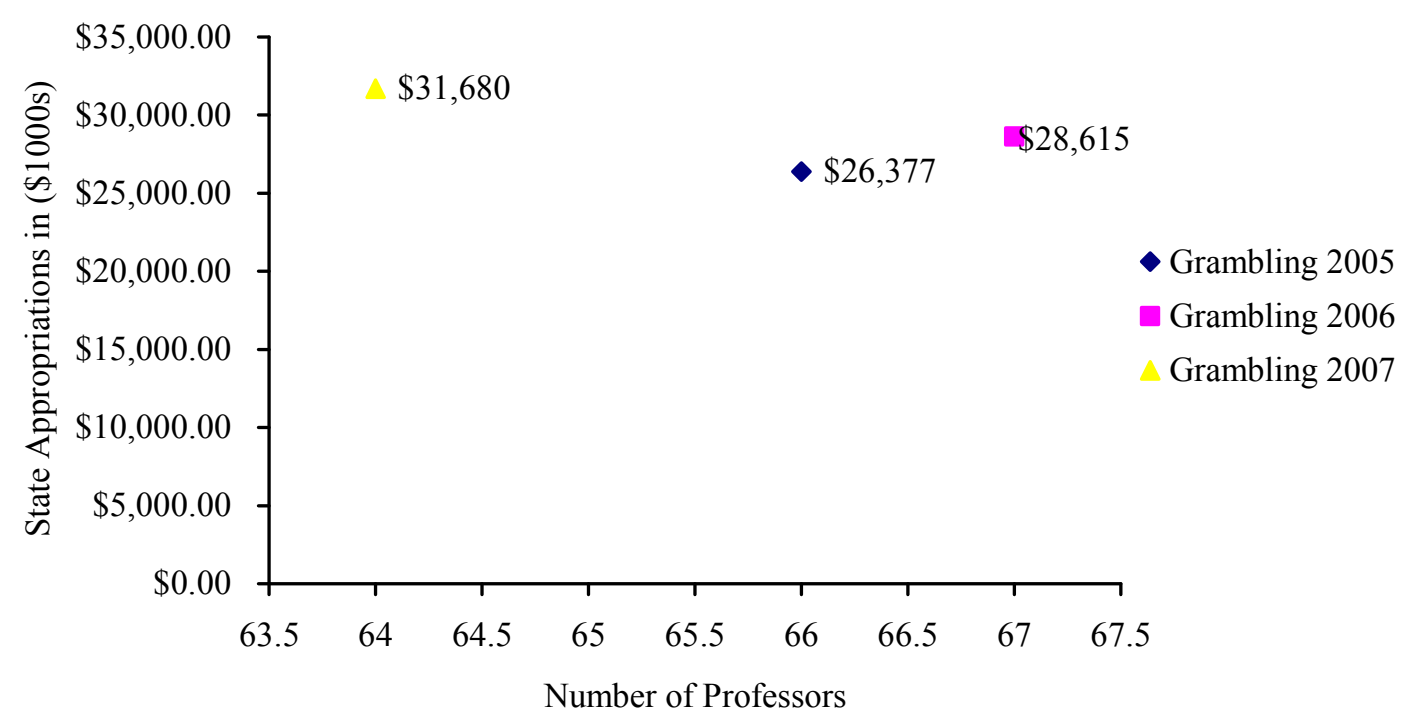

Figure 2: Impact of State Approriations on Number of Professors

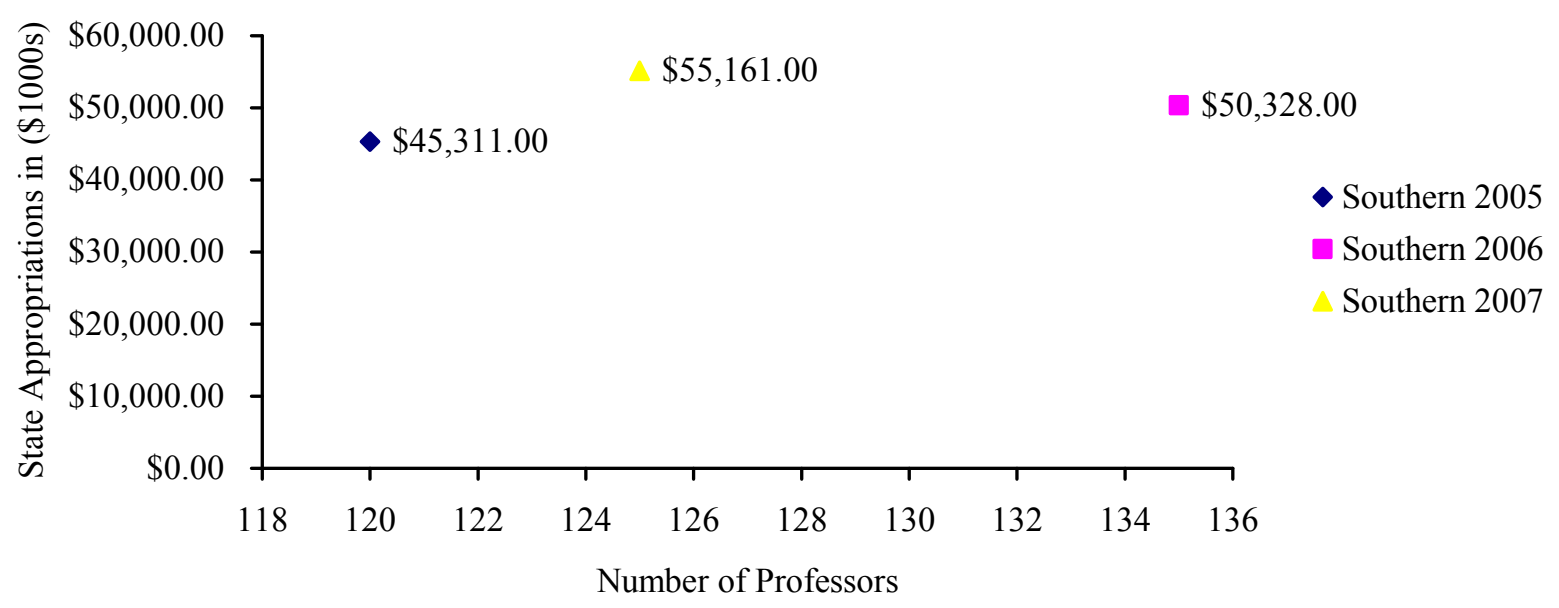

Figure 3: Impact of State Appropriations on Number of Professors 


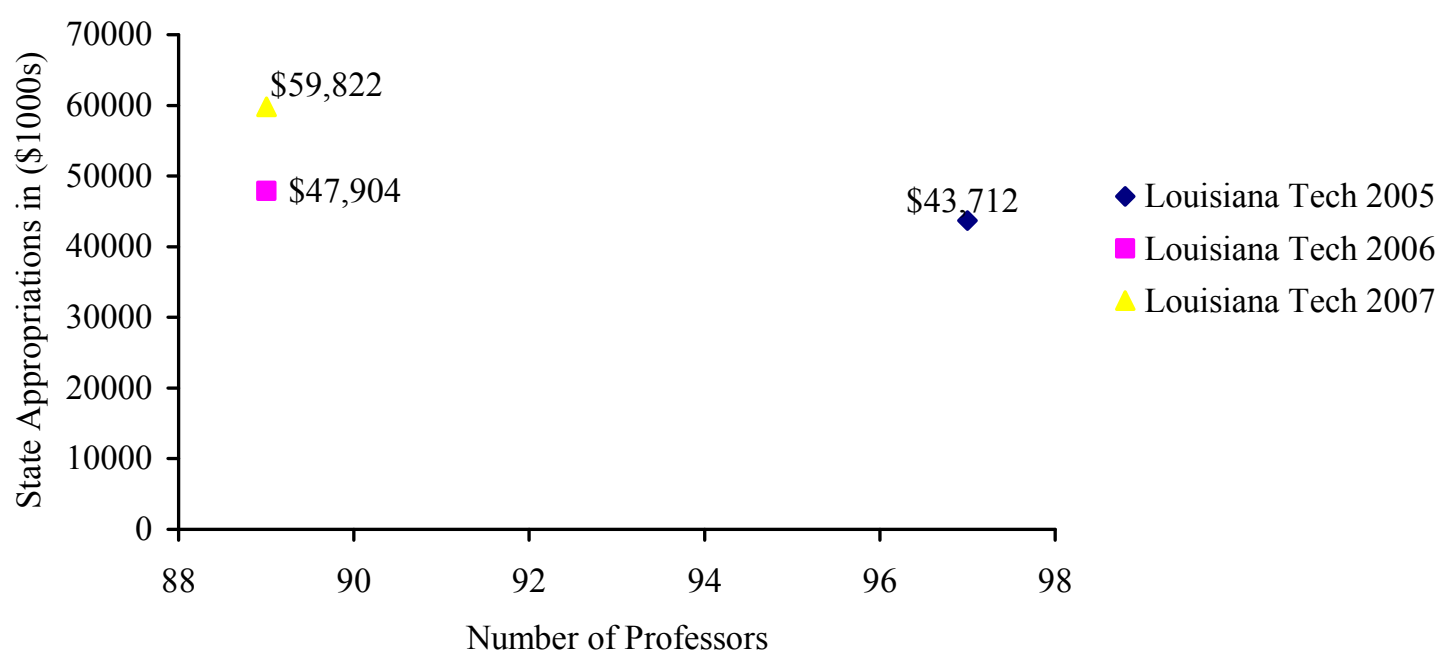

Figure 4: Impact of State Appropriations on Number of Professors

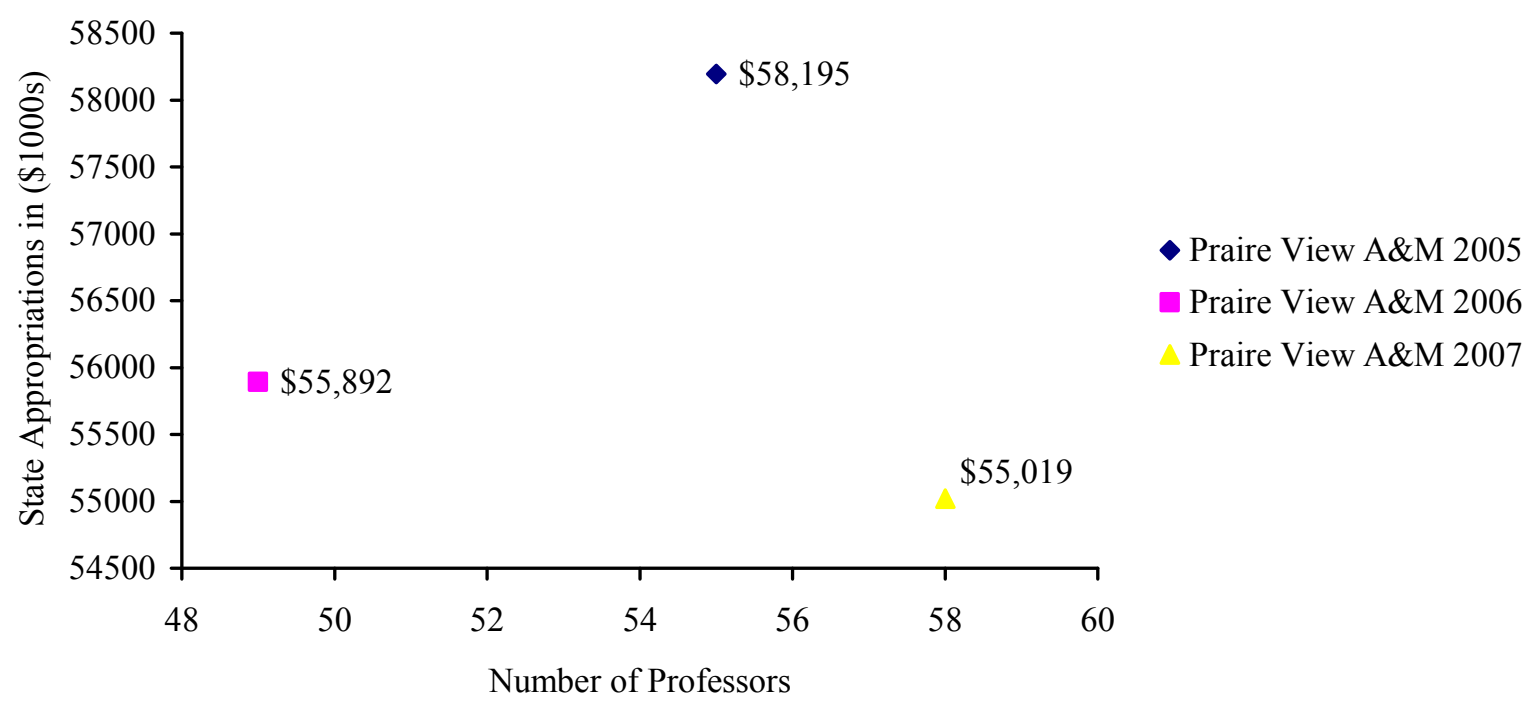

Figure 5: Impact of State Appropriations on Number of Professors

The information shows that at each school for the years 2005-2007 the highest numbers of professors was never located at the year with the highest state appropriations given to the University. We assume the number of professor that each university can afford to employ is dependent on additional factors. In addition to the state appropriations tuition, alumni resources, and other school fees all impact the University's revenue for each year. We next chose to analyze whether the percentage of state appropriation change impacts the percentage of change in the employment of professors. 


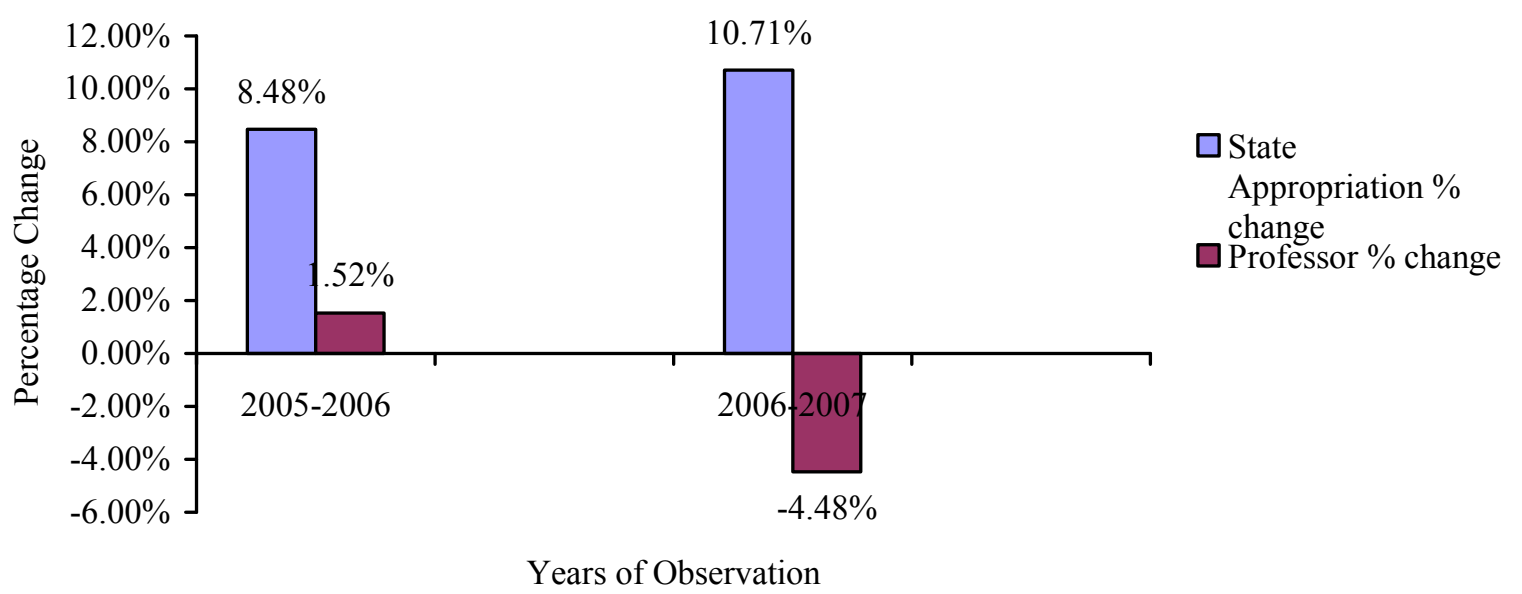

Figure 6: State Appropriations \% Change vs Professor \% Change

(Grambling State University)

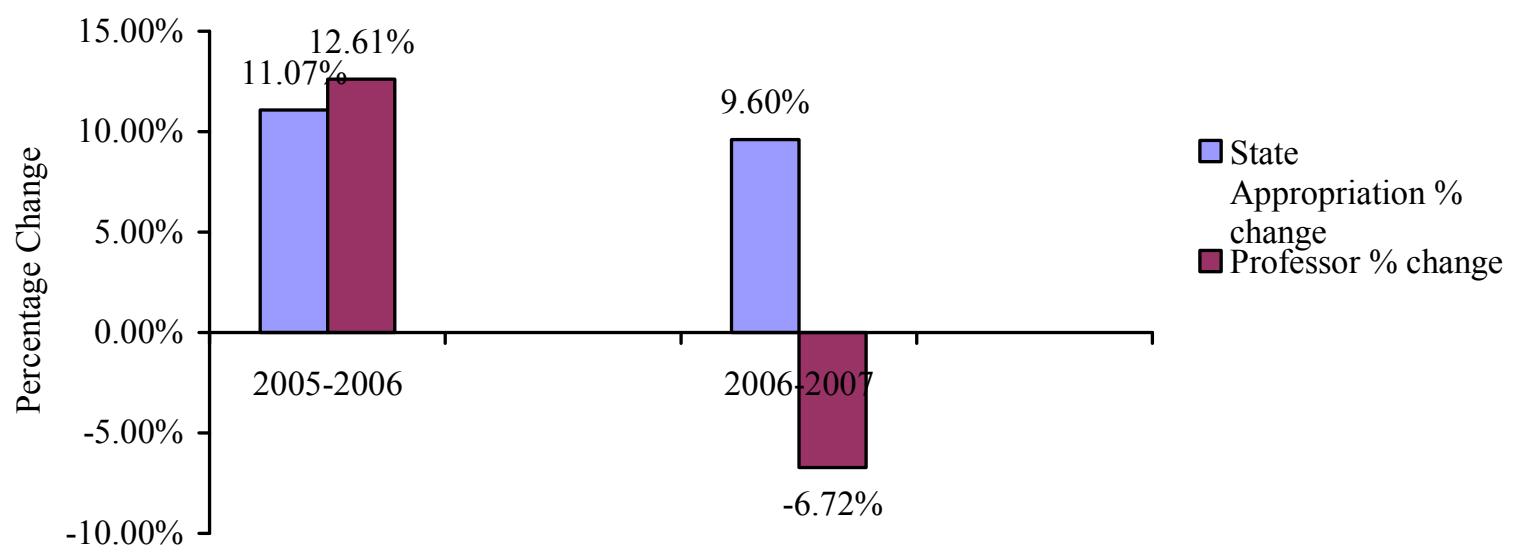

Years of Observation

Figure 7: State Appropriations \% Change vs Professor \% Change

(Southern University) 


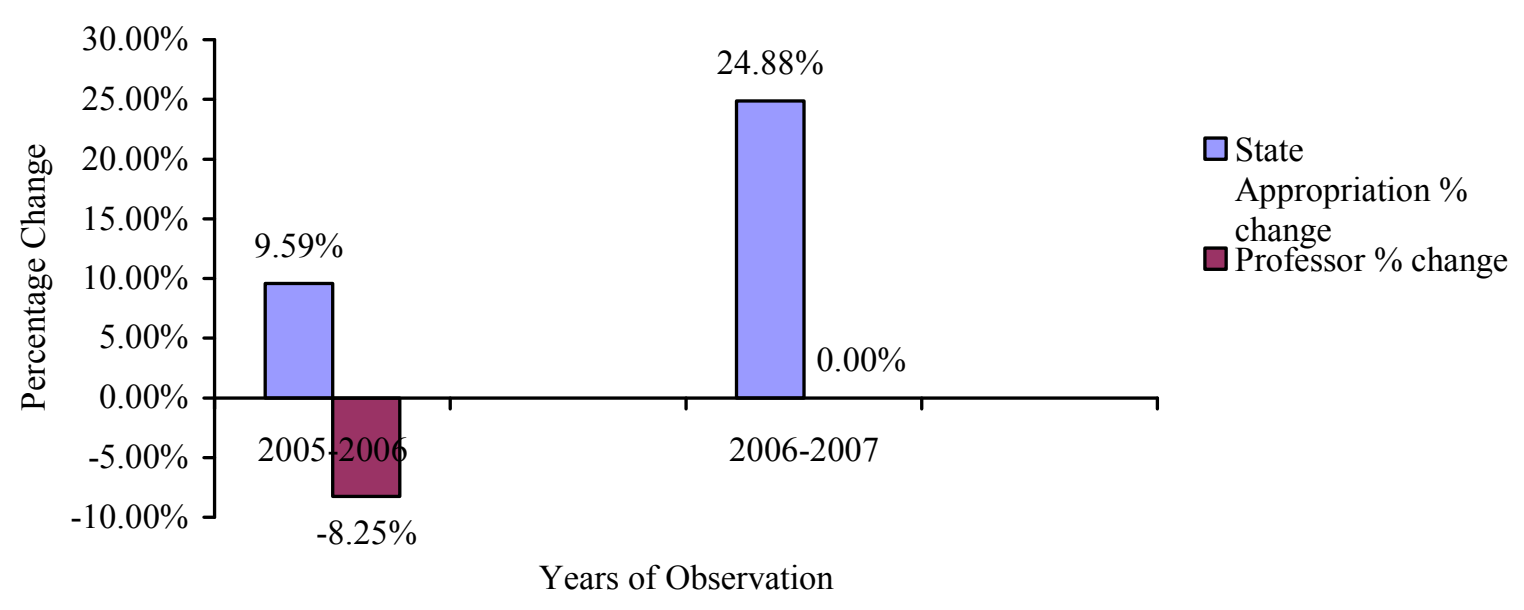

Figure 8: State Appropriations \% Change vs Professor \% Change

(Louisiana Tech University)

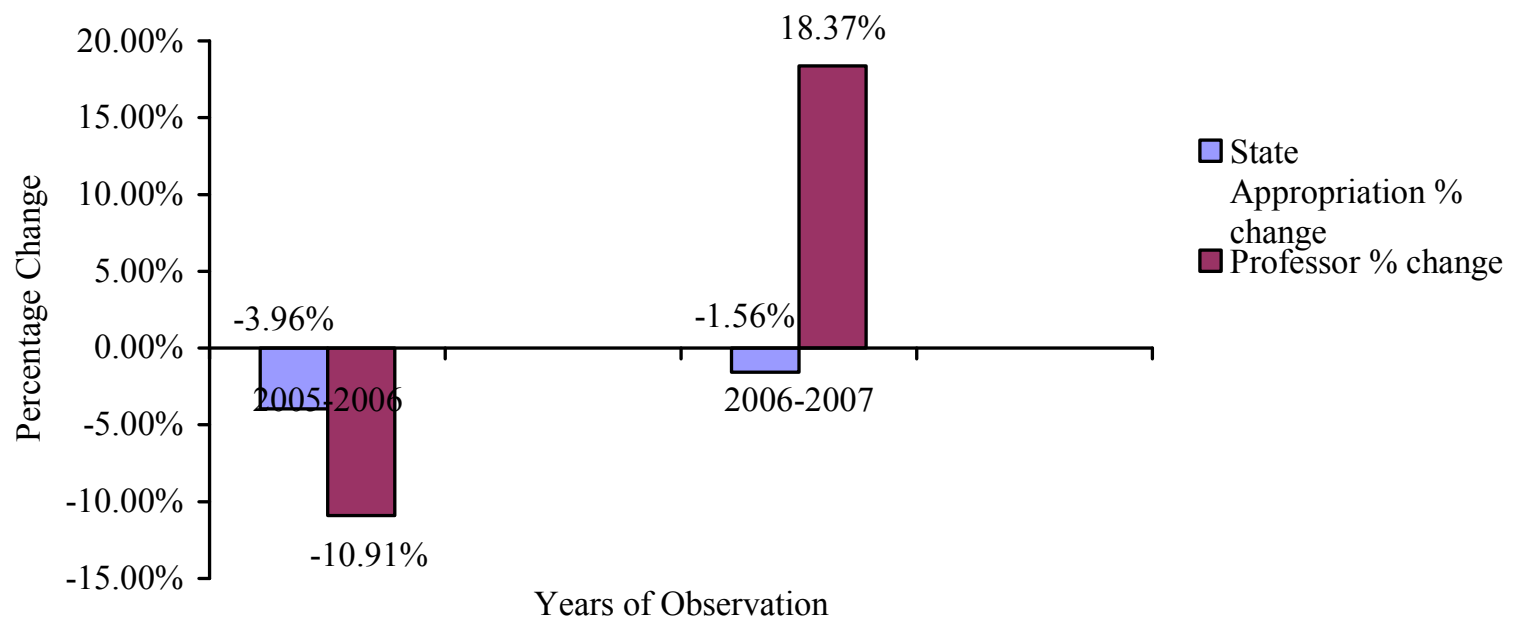

Figure 9: State Appropriations \% Change vs Professor \% Change

(Prairie View A\&M University)

We gathered from the above charts that a downturn could negatively impact factors of success for each university. The numbers of Professors that each university can employ is one example of the negative outcomes of downturn. You must be able to teach your students so that they can effectively compete in the world upon graduation. You must have quality research programs. Due to the economic downturn, historically black colleges and universities, such as Grambling State University have suffered tremendously. Historical black 
colleges and universities use a great amount of financial aid to get students to. Most students that attend these universities and colleges cannot get to school without the help of big loans or grants. Sixty-three percent of students at eighty-three of the 4 year historically black colleges and universities receive Pell Grants, and that is for only students who receive income of less than $\$ 40,000$ yearly (Haines). Only a few students at the university can get their school paid by parents. Most have to get jobs while in school to help pay for other needs such as books materials and a computer. We again analyzed information gathered b ISU's Grapevine Project. The following chart compares the Percentage of State Appropriations for higher education from 2005-2007.
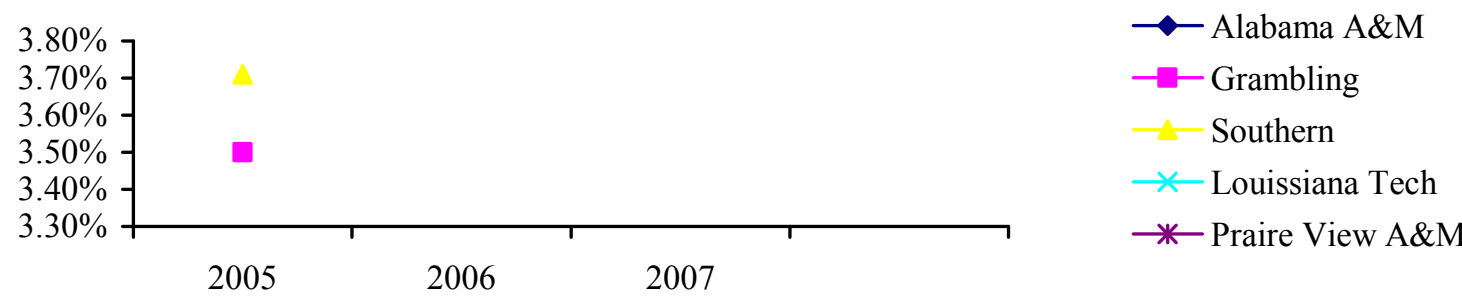

Figure 10: The Percentage of State Appropriations for Higher Education from 2005-2007

We found that each of the schools maintained a consistent percentage change rate, but that Louisiana Tech University had a steep drop from 3.50\% increase in 2005 to above 1\% increase in 2007. The school with the highest growth rate was Southern University and Prairie View A\&M University had the lowest growth rate.

As stated on www.nola.com enrollments at the schools have declined at the same time endowments fell three percent in the fiscal year ending June 30, and a smaller group estimated a twenty-three percent drop in the first five months of fiscal year 2009 that began in July was reported in a survey of 791 American public to students of the university. Other historical universities such as Atlanta's University Center, Spelman University, Clark Atlanta University, and Morehouse College announced that they are cutting cost measures that will sacrifice employees and educational programs.

If the economy continues to go the way it is other historical black colleges and universities will have to follow in the footsteps of their counterparts. Even before the economic recession America had worries about the rising cost in college tuition. Tuition increases are also impacting the ability for students to continue their education. The following charts show the impact of tuition on enrollment. I believe as tuition goes up enrollment will go down. I found that some of the data didn't indicate that much of a change in enrollment. Every school year, tuition goes up by a certain percentage which usually results in a decrease in enrollment numbers. The graphs were created from universities' fact books from collegetoolkit.com all schools are included in the graphs. 


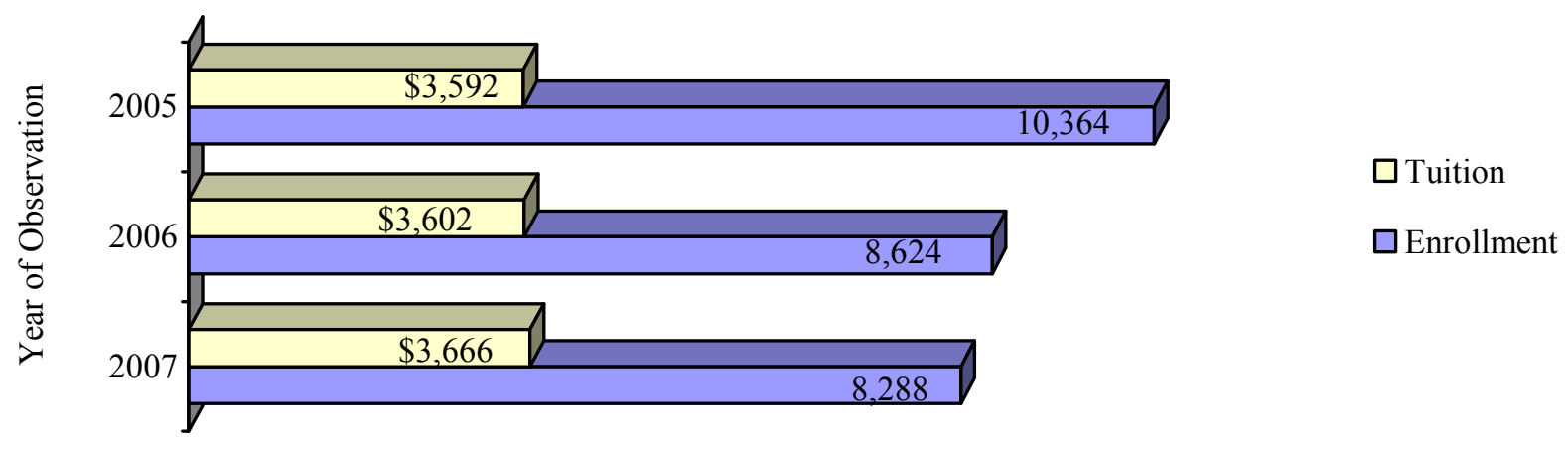

Figure 11: Tuition Vs Enrollment

(Southern University)

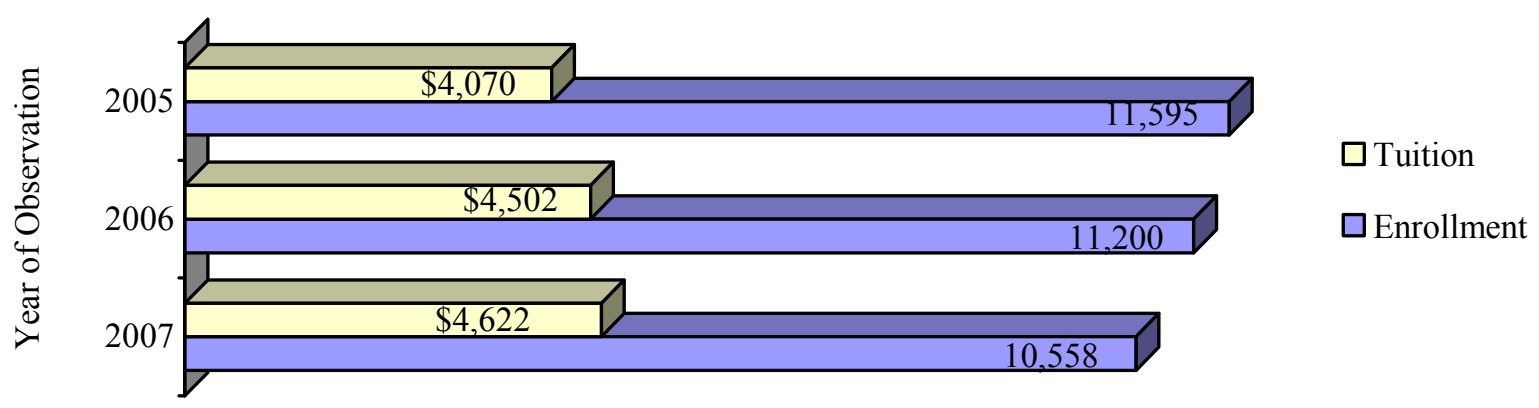

Figure 12: Tuition Vs Enrollment (Louisiana Tech University)

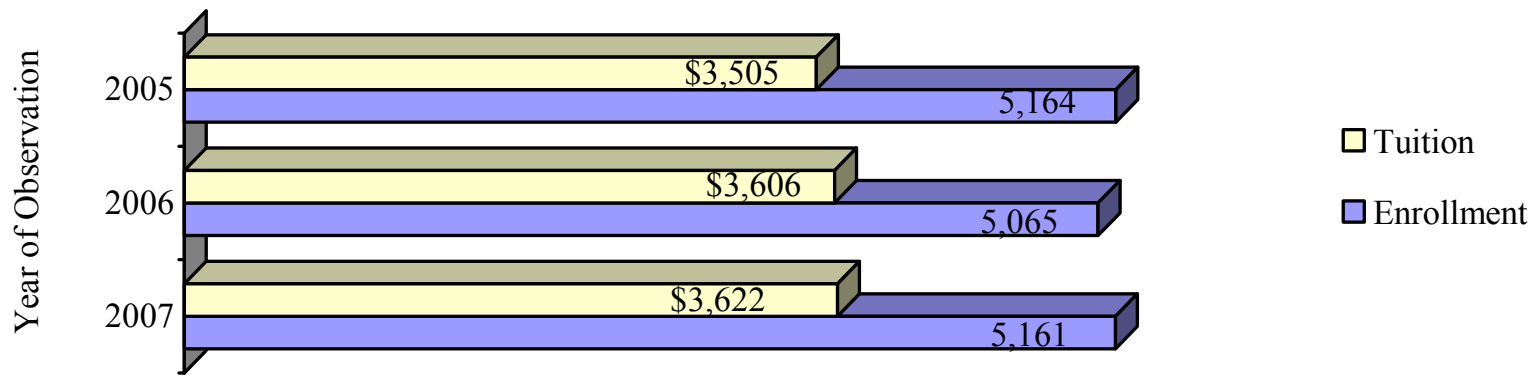

Figure 13: Tuition Vs Enrollment

(Grambling State University) 


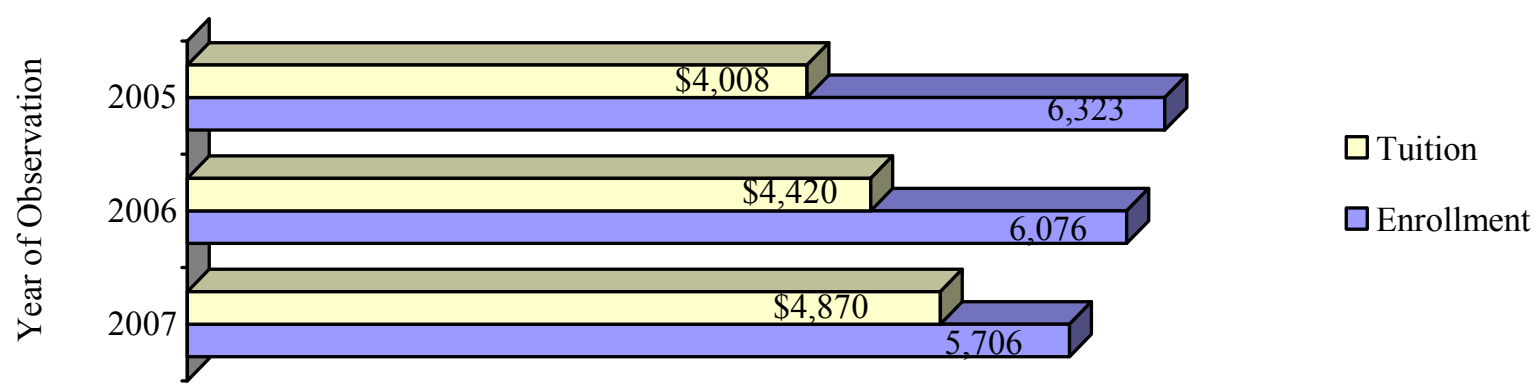

Figure 14: Tuition Vs Enrollment

(Alabama A\&M University)

The data shows that in four out of five of the universities the lowest tuition rates produced the highest enrollment rates. The only school that varied from the norm was Prairie View A\&M University. They may have had other factors that impacted a boost enrollment school. The following graph is showing is the University's tuition vs. Average tuition for the state. All information listed into this graph was compiled from each University's tuition vs. the average fact book, or CollegeToolKit.com. The following is showing each university's tuition vs. the average tuition for each state from 2006. This information was taken from measuringup.highereducation.com. It is up to the University to be equivalent with average tuition for the state. Average tuition for the state is set at a specific rate based on what you are in. Thus universities and students you are in. Thus universities and students can compare tuitions rates.

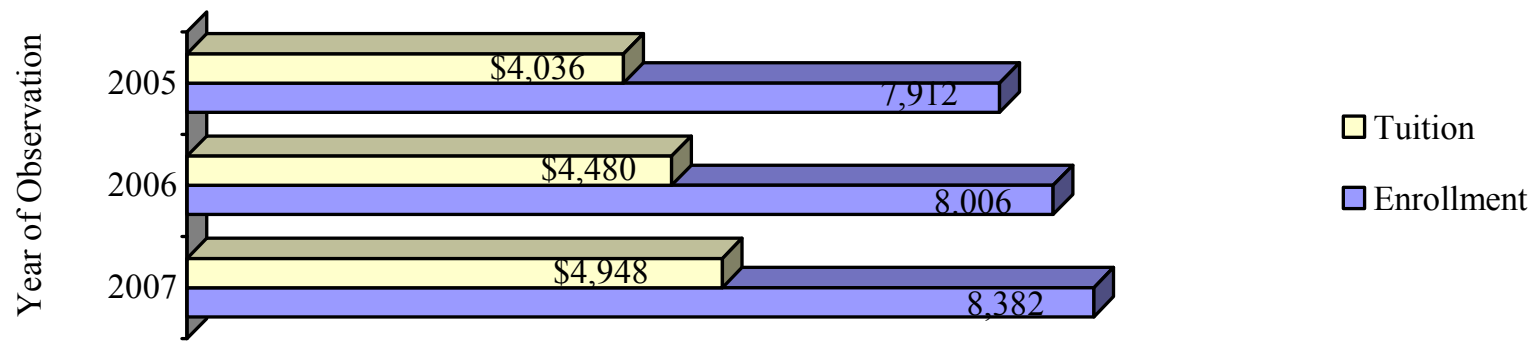

Figure 15: Tuition Vs Enrollment

(Praire View A\&M University) 


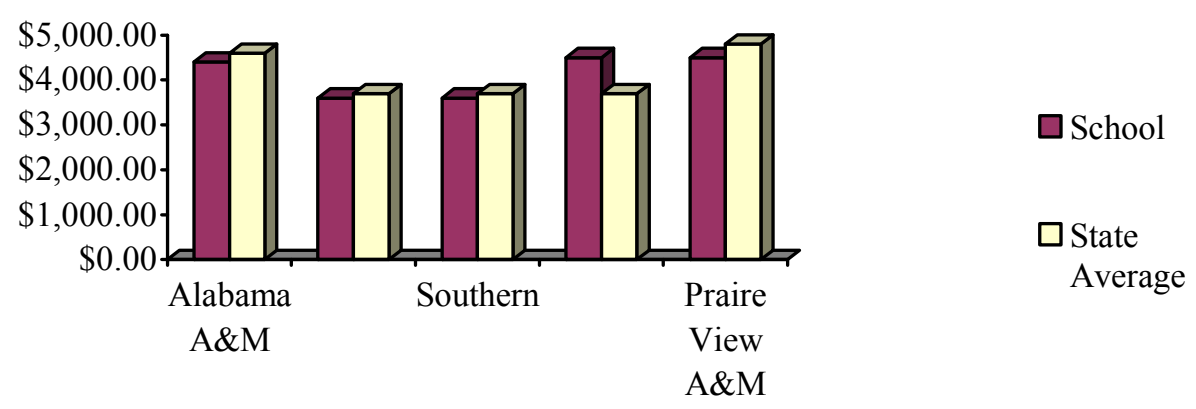

Figure 16: University's Tuition vs. Average State Tuition 2006

This year alone the UNCF has lost five million dollars in their revenues. Michael Lomax stated on www.thedefendersonline.org, "I'm not so sure our scholarships will be so affected this year, because they're budgeted for. AS far as our support to colleges, we're at risk of seeing some erosion in that. We're already hearing from foundations and corporations that they're being very cautious about what they are going to commit."

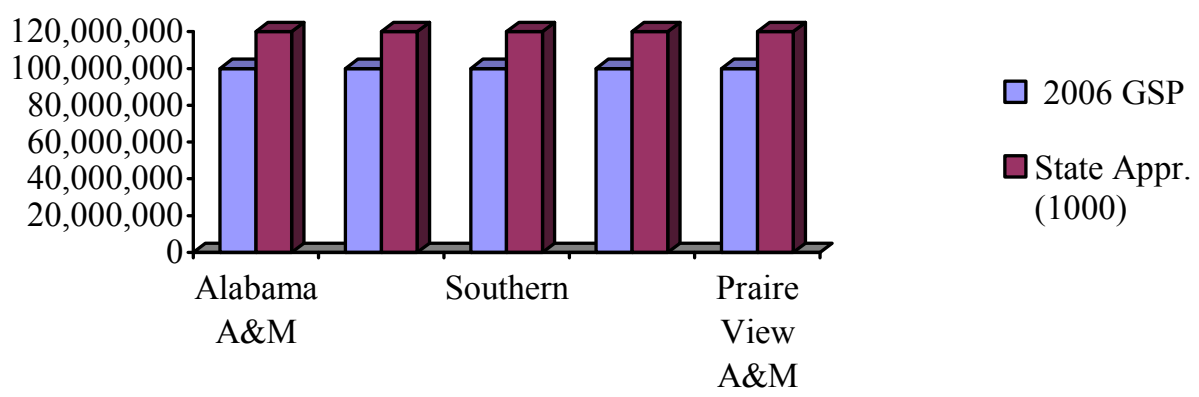

Figure 17: University's Tuition vs. Average State Tuition 2006

The chart above shows that each school has been pretty consistent in the ratio of Gross State Product to State Appropriations given to each university. The following is information from the Grapevine Compilation of State Higher Education Tax Appropriations Data compiled by James C. Palmer at Illinois State University. The grapevine project entails an annual compilation of data on state tax support for higher education, including general fund appropriations for universities, colleges, community colleges and state higher education agencies (Palmer). The following chart shows appropriations for the year 1998, 2003, 2006, 2007, and 2008. It also shows a 1, 2, 5 and 10 year percentage of change. 
Table 1: Appropriations of State Tax Funds for Operating Expenses of Higher Education of Fiscal Years 1998, 2003, 2006, 2007, and 2008 with Percentage of Change over the Most Recent One, Two, Five and Ten Years

\begin{tabular}{|c|c|c|c|c|c|c|c|c|c|}
\hline \multirow{2}{*}{ States } & \multicolumn{5}{|c|}{ Appropriations (\$1000) for the Fiscal Year } & \multicolumn{4}{|c|}{ \% Change } \\
\hline & 1998 & 2003 & 2006 & 2007 & 2008 & $\begin{array}{c}1 \mathrm{Yr} \\
(07-08)\end{array}$ & $\begin{array}{c}2 \mathrm{Yr} \\
(06-08)\end{array}$ & $\begin{array}{c}5 \mathrm{Yr} \\
(03-08)\end{array}$ & $\begin{array}{c}10 \mathrm{Yr} \\
(98-08)\end{array}$ \\
\hline Alabama & 978,473 & $1,162,194$ & $1,407,875$ & $1,684,901$ & $1,936,513$ & $14.9 \%$ & $37.5 \%$ & $66.6 \%$ & $97.9 \%$ \\
\hline $\begin{array}{l}\text { Louisiana } \\
* *\end{array}$ & 769,680 & $1,158,608$ & $1,242,769$ & $1,430,956$ & $1,656,927$ & $15.8 \%$ & $33.3 \%$ & $43.0 \%$ & $99.7 \%$ \\
\hline Texas & $3,558,936$ & $4,831,304$ & $5,242,541$ & $5,449,196$ & $6,058,375$ & $11.2 \%$ & $14.9 \%$ & $25.4 \%$ & $70.2 \%$ \\
\hline
\end{tabular}

**Grapevine files prior to fiscal year 2003 do not include Louisiana appropriations for the state's Tuition Opportunity Program for Students (TOPS). Therefore, the 10 year percent change reported (99.7\%) was calculated without including the Fiscal year 2008 appropriations for TOPS.

This information shows that going back from 2008 to 1998 we have had a positive increase in the state appropriations of Alabama, Louisiana, and Texas. This recession could possibly lead to negative growth in those state appropriations.

Table 2: Annual Percent Change in Total State Tax Appropriations for Higher Education Nationwide, Fiscal Year 2004

\begin{tabular}{lll}
\hline Fiscal Year & \% Change From the Previous Fiscal Year \\
\hline 2008 & $7.5 \%$ & \\
2007 & $7.1 \%$ & \\
2006 & $6.0 \%$ & \\
2005 & $3.8 \%$ & \\
2004 & $-2.1 \%$ & \\
\hline
\end{tabular}

In the Table "Annual Percent Change in Total State Tax Appropriations for Higher Education Nationwide, Fiscal Year 2004" compiled by James C. Palmer of Grapevine Compilation of State Higher Education Tax Appropriations Data shows the percentage of change from 2004- 2008 in total state tax appropriations. As you can see in 2004 state tax appropriations for higher education nationwide was at a negative percentage. As time progress each fiscal year percent change from fiscal year went into a positive change. What this is indicating is that downturn on higher education is relevant, which will result to budget cuts, endowment declines, and students finding it harder to make tuition because the increase in tuition. 
Table 3: State Appropriations for Higher Education in Recession Periods per Full Time Equivalent

\begin{tabular}{lcccccc}
\hline \multicolumn{1}{c}{ State } & $\begin{array}{c}\text { \% Change } \\
\text { State Funds } \\
(1980-1982)\end{array}$ & $\begin{array}{c}\text { Year of } \\
\text { Rebound } \\
\text { to 1980 } \\
\text { level }\end{array}$ & $\begin{array}{c}\text { \% Change } \\
\text { State Funds } \\
(1991-1993)\end{array}$ & $\begin{array}{c}\text { Year of } \\
\text { Rebound } \\
\text { to 1991 } \\
\text { level }\end{array}$ & $\begin{array}{c}\text { \% Change } \\
\text { State Funds } \\
(2001-2003)\end{array}$ & $\begin{array}{c}\text { Year of } \\
\text { Rebound } \\
\text { to } \\
\text { 2001 level }\end{array}$ \\
\hline Alabama & $-15.5 \%$ & 1988 & $-7.0 \%$ & 1995 & $-6.0 \%$ & $*$ \\
Louisiana & $9.0 \%$ & & $-11.9 \%$ & 1999 & $17.5 \%$ & \\
Texas & $17.2 \%$ & & $0.6 \%$ & & $-5.7 \%$ & $*$ \\
\hline
\end{tabular}

\section{Conclusion}

As we can see from the information found in the source Recessions that never end, the chart shows how change over time has affected all three states. During the years of 1980 through to 1982 we see that Alabama had suffered a major lost in state funds. It had a negative $15.5 \%$ but rebounded six years later in 1988. In the years 1991-1993, the state had a loss of a negative $7 \%$ in state funds and rebounded from that in 1995.then finally in 2001-2003 it had a negative 6\% and has yet to rebound from this. As over the years the change in funds slowly starts to get better over time. Louisiana's change in state funds is different from Alabama's state funds. During the 1980's, Louisiana's change in state funds was up 9\%. Then in 1991-1993 they had a decrease of $11.9 \%$ in the funds, and in 2001-2003 they had an increase by $17.5 \%$. This shows that the state of Louisiana is giving more money to higher education. Like Louisiana, Texas stated off strong on 1980-1982. It increased its state funds by $17.2 \%$. It then went down to $0.6 \%$ in 1991-1993 and by $2001-2003$ it had went down by $-5.7 \%$. This lets us know that now during the recession; Texas is probably not receiving enough funding from the state. We can also see that different states are suffering differently from the recession period.

We are in desperate need of stimulus funding. However we may never see the aide. With our economic setbacks comes much trouble for the state's 17 four year schools. Senator Mike Michot thinks that the state should look at cutting down some of the smaller four year institutions and convert them into community colleges (Louisiana State Budget). Many colleges are bracing for the bad news to come. The University of Louisiana System is expecting to take a budget cut. This could lead to negative impacts on all aspects of the business this includes less money to pay recruiters, less retention and less attention to buildings. "A loss of $\$ 116.4$ million to the UL System would mean that approximately 1500 positions would be terminated including in excess of 700 faculties, 300 unclassified professionals, 350 classified professionals and 40 graduate assistances position (Ball).

The control used in this analysis was Louisiana Tech University. We found that when comparing schools with the other Historically Black Universities, the results of most of the factors we compared produced similar findings. This validates the information of the other 
schools, and shows that various schools are having the same struggles, and shortfalls.

\section{References}

“2007-2008 E Fact book for Grambling State University" Grambling State University. 15 Mar. 2009. http://www.gram.edu/pair/docs/2008\%20GSU\%20Fact\%20Book.pdf

"Alabama State Report for 2009" Grapevine Project, Illinois State University. 15 Mar. 2009. Retrieved from http://www.grapevine.itsu.edu/statereports/FY09/pdf/AR_09_submission.pdf

Ball, Jr. "Butchering Our Future” Business Report. 9 Feb. 2009. 28 Feb 2009. Retrieved from http://www.businessreport.com/news/2009/feb/09/butchering-ourfuture/

"Board of Regents Halts New Programs." KATC. 8 Jan. 2009. 28 Feb. 2009. Retrieved from http://www.katc.com/global/story.asp?S=9643784

“Cost of attendance 2009 - 2010" Prairie View A\&M University. 15 Mar. 2009. Retrieved from http://www.pvamu.edu/pages/2167.asp

"Enrollment Statistics for Fall 2005" Alabama A\&M University. 15 Mar. 2009. Retrieved from http://www.galileo.aamu.edu/financialAid/2005-06budgets.htm

"Enrollment Statistics for Fall 2006" Alabama A\&M University. 15 Mar. 2009. Retrieved from http://www.aamu.edu/financial_aid/coa.aspx

"Enrollment Statistics for Fall 2007" Alabama A\&M University. 15 Mar. 2009. Retrieved from http://www.aamu.edu/irpsp/fact_book.aspx

"Enrollment Statistics for Fall 2008” Alabama A\&M University. 15 Mar. 2009. Retrieved from

http://www.aamu.edu/irsp/doc/oipre_docs/Enrollment_DemographicFall2008_Univ.pdf

"Fact Book 2003-2007" Prairie View A\&M University. 15 Mar 2009. Retrieved from http://www.pvamu.edu/Include/IR/Fact_books/2003-2007/07-Factbook-final.pdf

"Fall 2007 Tuition Schedule" Southern University. 15 Mar 2009. Retrieved from http://www.subr.edu/registration/2007FallFeesTuition.pdf

"Fall 2008 Tuition Schedule" Southern University. 15 Mar 2009. Retrieved from http://web.subr.edu/fileadmin/files/pdf/FallFee08.pdf

“Grambling Enrollment Statistics 2005" Grambling State University. 15 Mar 2009. Retrieved from http://www.gram.edu/pair/docs/2008\%20GSU\%20Fact\%20Book.pdf

“Grambling Fee Sheet Schedule 2006-2007” Grambling State University. 15 Mar 2009. Retrieved from http://www.gram.edu/registrar/undergraduatefees.asp

Haines, Erin. "Historically Black Colleges acutely feeling the pain of Economic Downturn."

The Associated Press 15 Jan 2009. 28 Feb 2009. Retrieved from 
http://www.nola.com/news/index.ssf/2009/02/hiistorically_black_collegesac.html

"Louisiana State Budget." Sunshine Review. 28 Feb 2009. Retrieved from http://www.sunshinereview.org/index.php/Louisiana_state_budget

"Louisiana Tech Fact Book 2003-2007". 15 Mar 2009. Retrieved from http://www.latech.edu/ir/assets/fact-book-2003-2007.pdf\#fac5year

“Louisiana Tech Tuition for 2005-2007". 15 Mar 2009. Retrieved from http://colleges.collegetoolkit.com/colleges/tuition-financial-aid/louisiana_tech_universit $\mathrm{y} / 159647 . \operatorname{aspx}$

“Mississippi State Report for 2009” Grapevine Project, Illinois State University. 15 Mar 2009. $\begin{array}{ll}\text { Retrieved from } & \text { from }\end{array}$ http://www.grapevine.ilstu.edu/statereports/FY09/pdf/MS_09_Submission\%202.pdf

Palmer, James C “Grapevine Project” Illinois State University 15 Mar 2009. Retrieved from http://www.grapevine.ilstu.edu/index.shtml

"Prairie View A\&M University Fast Facts" CSO College Center. 15 Mar 2009. Retrieved from http://www.csocollegecenter.org/collegeinfo.aspx?id=315

"Prairie View A\&M University Tuition 05-07" 15 Mar 2009. Retrieved from $\mathrm{http} / / /$ www.collegetoolkit.com/college/tutition-financial-aid/prairie_view_a_and_muniv ersity/227526.aspx

"Enrollment data For Southern by campus" Southern University System. 15 Mar 2009. Retrieved from http://www.sus.edu/VPASA/docs/statistics.pdf

"Southern Fact Book" Southern University. 15 Mar 2009. Retrieved from http://www.websubr.edu/fileadmin/files/PAIR/Fact_Book_2007-08_10-31-08.pdf

"Spring 2009 Tuition Schedule" Southern University. 15 March 2009. Retrieved from http://web.subr.edu/fileadmin/files/pdf/Spring2009.pdf

"State Appropriations for 2007-2008" Grapevine Project, Illinois State University. 15 mar 2009.

Retrieved

from http://www.grapevineilstu.edu/historical/Appropriations\%202007-08.pdf

"State Appropriations for 2006-2007" Grapevine Project, Illinois State University. 15 mar 2009. Retrieved

from http://www.grapevineilstu.edu/historical/Appropriations\%202006-07.pdf

"State Appropriations for 2005-2006" Grapevine Project, Illinois State University. 15 mar 2009. Retrieved from http://www.grapevineilstu.edu/historical/Appropriations\%202005-06.pdf

Stovall, TaRessa. "Economic Crisis Hits Historically black Colleges Hard.” 10 Dec 2008. NAACP Legal defense

Educational Fund. 04 Mar 2009. Retrieved from http://www.thedefendersonline.com 


\section{Macrothink}

International Journal of Education

ISSN 1948-5476 2012, Vol. 4, No. 4

“Texas State Report for 2009” Grapevine Project, Illinois State University. 15 Mar 2009. Retrieved from http://www.grapevine.iltsu.edu/statereports/FY09/pdf/TX_09_submissson.pdf

\section{Copyright Disclaimer}

Copyright reserved by the author(s).

This article is an open-access article distributed under the terms and conditions of the Creative Commons Attribution license (http://creativecommons.org/licenses/by/3.0/). 